\title{
Fun Activities Game to Improve Students' Vocabulary in Elementary School
}

\author{
RintaAryani ${ }^{1}$ and Fria BintangListiawati ${ }^{2}$ \\ Semarang State University, Indonesia
}

\begin{abstract}
English has four skills that should be mastered by the students. They are listening, speaking, reading, and writing. In order to mastering English well. The first step that students can do is mastering the vocabulary. This is the basic thing in this language. English teachers teach English based on Curriculum. But, as a matter of fact, students still face difficulties in learning English. One of them is about how to master English vocabularies. There are many factors why students face difficulties in mastering vocabularies. One of the factor is there isn't interesting media used by the teachers in teaching English. So, students can get bored easily and it makes students think that learning English is not fun. That is why students lack their ability in mastering vocabularies. Based on this problem, the researcher proposed an idea that has purpose to improve students' vocabulary, entitled Fun Activities Game to Improve Students' Vocabulary in Elementary School This research used qualitative method. There are many activities in this research. They are pretest, giving material, flash card game, work in groups, reviewing the vocabularies, and posttest. All of those activities are hoped to help students mastering the vocabulary easily and make the students feel happy in learning English. So, students can improve their ability in mastering the vocabulary.
\end{abstract}

Keywords: Fun Activities, Teaching, Vocabulary

\section{Introduction}

Language is a means of communication. It plays a very important role in social relationship among human beings. Ramelan (2003:1) states that "language is used to express idea, thought, and feelings to the other people. People in a society use language, which mutually understood to communicate with others".

The increasing need caused by developing era demands the global society to enhance their human resources quality in order to compete to the other countries. In responding this situation, the role of communication has become a part that could not be separated from this condition. As English has become very powerful language in the world, it become one of international languages, most global community use English as a media of communication with another person. Ricardo Schutz (2007) said that English in its role as a global language that it had become one of the most important academic and professional tools. English had become the official language of the business and scientific worlds.

Mohammad Reza Talebinezhad\& Mohammad Aliakbari ( 2007) said that English as an International Language referred to the use of English by people of different nations in order to communicate with one another.

Indonesia puts English as their foreign language. It is used as an instrument of utilizing modern sciences and technology for national development and it is also used as a mean of communication when Indonesia want to communicate to people from overseas. No doubt that only few Indonesians master of it, most of them tend to ignore it, they use to think that foreign language is not something useful for their daily life and learn of it would only waste of time.

However, nowadays the assumption is gradually scrap off by the developing era that demands the society to be more competitive and to be able to enhance their human resources quality. Since English recently is treated as a foreign and important language for Indonesia, it has a major portion in Indonesian educational system and become a compulsory subject to study either in junior or senior high school in today's Indonesian educational system. 
In line with the government's plan to have nine compulsory studies, it is possible to teach English in elementary school. By applying the foreign language to early level (elementary school students), the students' language mastery is expected to be satisfactory although it is only in simple English. As I know since English mostly become difficult subject, it handicapthem (students in any level) all the time whenever they do an English test, this condition will certainly affect to their result of study.

In teaching a language, a teacher might realize that he could not apply only one strategies or two strategies to all levels. In reverse, he is required to be able to recognize the characters of his students and to select an appropriate strategy to them. It is not something different from teaching English to elementary school students, the teacher is supposed to know that children are so closed with something fun and enjoyable because, the students in elementary school has a limited attention span, it would make them easily get bored and losing interest after ten minutes or so. So whenever the teacher teaches, he has to be selective in choosing a strategy to introduce a learning material. A good teaching strategy would automatically facilitate him to get students' interest in learning process.

Teaching English vocanulary to children as early as possible will improve their ability in mastering English so that they have a lot of preparation to face English matter in the future. English for the students of elementary school is thir first foreign language. They learn English for the first time so, they just learn simple English pattern including grammar and vocabulary. Vocabulary is central to language and of critical importance for language learner. Without sufficient vocabulary, one cannot communicate effectively or express their ideas in both oral and written form. Having limited vocabulary is also a barrier that precludes learners from learning foreign language. When they do not know how to enrich their vocabulary, for example, they often gradually lose interest in learning. The most efficient language learning must based on the real nature of both language and learning. This simple observation means we do need to reflex the lexical nature of language in the classroom as well as knowledge of enough word.

The teaching process could be started from earliest step, by using simple things without trying to introduce language components explicitly before they are really ready. After all the material of the pre-level were clearly taught and understood. The language components could be little involved in their study as a continuity of their learning, such as phonology, spelling, structure and vocabulary. Those components could not properly be separated that it because they are related among one to the other components.

One of the most important language components is vocabulary. According to Linda Diamond and Linda Gutlohn (2005) in their article they say that Vocabulary is the knowledge of words and word meaning. As Steven Stahl (2005) puts it, "Vocabulary knowledge is knowledge; the knowledge of a word not only implies a definition, but also implies how that word fits into the world". The mastery of it would be very helpful when one was learning foreign language having a great mastery on it; it would also facilitate him to comprehend the subject learnt in which it was in English. The quality of one's language skill depends on the quality and the quantity of vocabulary mastered, the more he masters the vocabulary the better he uses the language skill.

This study would present a vocabulary teaching strategy to elementary school students. In which it is going to be very pleasant and interesting for young learners. The teaching strategy is about fun activities for students of elementary school to improve their vocabulary.

\section{Research Method}

The object of this study was student of Elementary School in Tambak Lorok Semarang, Indonesia who joined in ASA EDU Community. We took a sample by using cluster sampling. We took 16 students of elementary school to make it more effective in collecting data.

The researcher used some steps in collecting data. First, students were introduced to this fun activities. Second, doing the implementation this strategy. Third, controlling and noticing the process by giving questionnaire from and deep interview. Fourth, classifying data. Fifth, analyzing data and making conclusion of this study 
The data was divided into two. Primary data and secondary data. The primary data was taken from the result of data interview and observation of the students. Meanwhile, the secondary data was taken from relevant source such as journals, books and trusted articles.

\section{Finding and Discussion}

There are many activities in this research that are given to the students. It relates to the idea of the research. Fun Activities consist of many activities. They are pretest, giving material, flash card game, work in groups, reviewing the vocabularies, and posttest. The explanation of each activities can be seen above:

- Pretest

Pretest was given to the students to know about the basic skill and knowledge of the students. Especially about students 'vocabulary mastery. Pretest was given in the first step because it will help the researcher to understand students' ability in vocabulary mastery and also to know the basic problem of the students regarding this study. Based on the result of pretest, the researcher could know how to improve students' ability in mastering vocabulary. It was very important, because based on pretest activity, it is not only giving advantage for the researchers to know students' problem of vocabularies mastery, but also the students could know the purpose of the researcher why they gave that research.

TABLE I. The Pre Test's Result

\begin{tabular}{|l|l|l|l|}
\hline Number & Name & Correct answer & False answer \\
\hline 1 & Bima & 3 & 7 \\
\hline 2 & Nugroho Putra Setiawan & 4 & 6 \\
\hline 3 & Zahra & 3 & 7 \\
\hline 4 & Ridwan & 4 & 6 \\
\hline 5 & Dita Cahyani & 1 & 9 \\
\hline 6 & Dinda Ayu & 3 & 7 \\
\hline 7 & Lutfi & 2 & 8 \\
\hline 8 & Fatin & 3 & 7 \\
\hline 9 & Abi Maulana & 2 & 8 \\
\hline 10 & Bunga & 3 & 7 \\
\hline 11 & Zaneta Aurelya Safitri & 5 & 5 \\
\hline 12 & Izzah & 4 & 6 \\
\hline 13 & Najua & 3 & 7 \\
\hline 14 & Damar & 4 & 6 \\
\hline 15 & Irfan & 2 & 8 \\
\hline 16 & Abi & 0 & 10 \\
\hline 17 & Melani A & 5 & 5 \\
\hline
\end{tabular}

The result of the research showed that the ability of vocabularies mastery of the students still needs an improvement. It could be seen when they answered the questions in pretest. There are many questions that difficult enough to be answered. Most of them got wrong answer in the same number of questions. They had same difficulties in the same number. After pretest was done, the researcher asked to the students why they got difficulties in the same number of question, they answered that they did not understand the meaning of words in that questions. So, it was clear that vocabularies mastery became the basic problem why the students felt difficult to answer in some question. It was because the lack of ability on students' vocabularies mastery.

Based on this result, then the researcher would like to implement many activities which is called Fun Activities. It has a purpose to help the students to improve their vocabularies mastery.

- Giving material

The second activity of Fun Activities program is giving material that was given by the researchers to the students. The material that was given relates to the vocabularies improvement. So, the researchers gave some new vocabularies and its meaning. Besides, the researcher also gave a strategy how to remember those new vocabularies easily. In this activity, the researcher also implemented Audio Lingual Method (ALM). It is a method that has a purpose to train the students in how to memorize and pronounce the new vocabularies by repeating what researcher said. So, the researcher would pronounce the vocabularies first, then, the students 
repeated it until they memorize it automatically. In this step, the researcher used power point and LCD as a media to deliver the material. The researcher showed the material on LCD projector. the students felt happy to learn it. It was because they liked the material that was given it was not only consist of new vocabularies and its meaning, but also the researcher provided some pictures to help students can memorize the words easily by looking at the pictures. Here is the example of Audio Lingual Method (ALM):

The researchers: ok children, today we will learn about vocabularies. It is about sea animal. Now, you can repeat after me. Ok?

The students: ok

The researcher: whale

The students: whale

The researcher: Shark

The students: shark

Audio Lingual Method gave positive impact to the students. It could train the students to improve their memories in memorizing the vocabularies. It was not only helped them to memorize how to pronounce the vocabularies, but also it taught the students to know the transcription.

- Flash Card Game

In this activity, the researcher gave some cards to the students. The cards were about the vocabularies of sea animal's name. In those cards, there was no transcription. It aimed to trained the students to memorize the words. So, based on Audio Lingual Method and flash card game, the researcher hope that the students could memorize the vocabularies well.

- Work in groups

The students were divided into two groups. Each group, would be given many cards. Then the researcher held a game. the game was about guessing the name of sea animal. So, the researcher show a picture as a clue. Then the captain of the group would guess what is the name of the sea animal based on the picture that the researcher gave.

- Reviewing the vocabularies

It is about recalling back many vocabularies that they have learnt. So, the researcher showed the pictures as a clue without showing the transcription. After the researchers showed this, the students had to guess the name of the pictures. It was not only about the correct answer, but also the correct pronunciation. So, the students could memorize how to pronounce it well. The researcher had to make sure that all of the students could memorize and pronounce the vocabularies well by checking them one by one orally. It became an indicator for the students. So the researchers could know how the students could understand the material well.

- Posttest

TABLE II. The Pre Test's Result

\begin{tabular}{|l|l|l|l|}
\hline Number & Name & Correct answer & False answer \\
\hline 1 & Bima & 7 & 3 \\
\hline 2 & Nugroho Putra Setiawan & 8 & 2 \\
\hline 3 & Zahra & 10 & - \\
\hline 4 & Ridwan & 9 & 1 \\
\hline 5 & Dita Cahyani & 6 & 4 \\
\hline 6 & Dinda Ayu & 10 & - \\
\hline 7 & Lutfi & 7 & 3 \\
\hline 8 & Fatin & 10 & - \\
\hline 9 & Abi Maulana & 6 & 4 \\
\hline 10 & Bunga & 10 & - \\
\hline 11 & Zaneta Aurelya Safitri & 9 & 1 \\
\hline 12 & Izzah & 10 & - \\
\hline 13 & Najua & 7 & 3 \\
\hline 14 & Damar & 10 & - \\
\hline 15 & Irfan & 9 & 1 \\
\hline 16 & Abi & 8 & 2 \\
\hline 17 & Melani A & 10 & - \\
\hline
\end{tabular}


From the table above, we can conclude that the students could catch and understand the material well. It could be seen from the pot test score. Most of them answered the correct answer based on the questions those the researchers gave.

\section{Conclusion}

Based on the research, the researchers can conclude that this program gave positive impact to the students in enlarging their vocabularies based on the activities those were given by the researchers. There are some points of the conclusion. They are:

- These activities could help students to improve their vocabularies. It was because in this program, the researchers used interesting media and method of learning, so the students felt interested in joining the learning process.

- There are many activities those were implemented by the researchers to the students. They are pre test, giving material, flash card game, work in groups, reviewing the vocabularies, and post test. each activity gave its benefit to the students. Pre test was conducted to know the students' basic skill of English, giving material was conducted to give them an understanding about what material that would be learnt, flash card game is an interesting game about remembering and guessing the pictures those were given. It also avoided them to get bored during the learning process. Work in groups taught them how to build teamwork. It was also about a game. Reviewing the vocabularies. It was about recalling the vocabularies they had learnt. Post test was conducted to know the result of students' learning process. So the researchers can conclude whether the program succeed or not.

- These activities could help the students in improving their vocabularies that can be seen in pre test and post test result.

\section{References}

[1] Diamond, Linda \& Gutlohn, Linda. (2006). Teaching Vocabulary. www.Ldonline.org/aricle/9943, accessed in February 9, 2018

[2] Ramelan. 2003. English Phonetics. Semarang: IKIP Semarang Press

[3] Reza, Talebinezhad, Mohammad \&Aliakbari, Mohammad.(2007). Basic Assumption in Teaching English as an International Language.www. Arts.cornell.edu/econ/azussman/English.pdf, accesed in February 10, 2018

[4] Schutz, Richardo. (2004). The International Language. www. sk.com.br/sk-ingl.html, accessed in February 10, 2018

[5] Stahl, Steven. (2005). Teaching Vocabulary. www.Ldonline.org/article/9943, accessed in February 9, 2018 